\title{
Very Low Nitrogen Leaching in Grazed Ley-Arable-Systems in Northwest Europe
}

\author{
Hendrik P. J. Smit ${ }^{1, *(\mathbb{D})}$, Thorsten Reinsch ${ }^{1}\left(\mathbb{D}\right.$, Christof Kluß ${ }^{1}\left(\mathbb{D}\right.$, Ralf Loges $^{1}$ and Friedhelm Taube ${ }^{1,2}$ \\ 1 Institute of Crop Science and Plant Breeding, Grass and Forage Science/Organic Agriculture, \\ Christian-Albrechts-University Kiel, Hermann-Rodewald-Straße9, D-24118 Kiel, Germany; \\ treinsch@gfo.uni-kiel.de (T.R.); ckluss@gfo.uni-kiel.de (C.K.); rloges@gfo.uni-kiel.de (R.L.); \\ ftaube@gfo.uni-kiel.de (F.T.) \\ 2 Grass Based Dairy Systems, Animal Production Systems Group, Wageningen University (WUR), \\ 6700 HB Wageningen, The Netherlands \\ * Correspondence: hsmit@gfo.uni-kiel.de
}

Citation: Smit, H.P.J.; Reinsch, T.; Kluß, C.; Loges, R.; Taube, F. Very Low Nitrogen Leaching in Grazed Ley-Arable-Systems in Northwest Europe. Agronomy 2021, 11, 2155. https: / / doi.org/10.3390/ agronomy11112155

Academic Editor: Daniel Real

Received: 22 September 2021

Accepted: 25 October 2021

Published: 27 October 2021

Publisher's Note: MDPI stays neutral with regard to jurisdictional claims in published maps and institutional affiliations.

Copyright: (C) 2021 by the authors. Licensee MDPI, Basel, Switzerland. This article is an open access article distributed under the terms and conditions of the Creative Commons Attribution (CC BY) license (https:// creativecommons.org/licenses/by/ $4.0 /)$.

\begin{abstract}
High input dairy farms that are located on sandy soils in northwest Europe are predisposed to substantial nitrate leaching during a surplus of winter precipitation. Leys within integrated croplivestock systems play an important role in soil fertility, soil C sequestration and soil $\mathrm{N}$ mineralization potentials. Therefore, leys are a feasible option that can be utilized to reduce local $\mathrm{N}$ losses to the environment, especially following maize grown for silage. We hypothesize that grass-clover leys ensure low nitrate leaching losses even when grazed intensively. The extent to which $\mathrm{NO}_{3}$-leaching occurred across seven different pasture management systems in terms of their sward composition, cutting, grazing, fertilization and combinations thereof was investigated in integrated animal-crop grazing systems over three winter periods (2017/2018, 2018/2019 and 2019/2020). The observed grazed systems were comprised of cut-used- and grazed grass-clover swards (0, 1 and 2 years after establishment following cereals), a catch crop grazed late in the year as well as a cut-used permanent grassland for comparison. Overall, all treatments resulted in nitrate leaching losses that did not exceed the WHO-threshold ( $25 \mathrm{mg}$ nitrate/L). The highest level of $\mathrm{NO}_{3}$-leaching was observed in the catch crop system and the lowest in cut-used permanent grassland, with $\mathrm{NO}_{3}-\mathrm{N}$ losses of $19.6 \pm 5.3$ and $2.1 \pm 0.3 \mathrm{~kg} \mathrm{NO}_{3}-\mathrm{N} \mathrm{ha}^{-1}$ year $^{-1}$. Annual herbage yields were in the range of 0.9 to $12.4 \mathrm{t} \mathrm{DM} \mathrm{ha}^{-1}$ and nitrogen yields varied between $181 \pm 51$ and $228 \pm 66 \mathrm{~kg} \mathrm{~N}^{-1}$ during the study period. The highest herbage- $\mathrm{N}$-yields were observed from the 1- and 2-year-old grass-clover leys. The highest N-field-balance was observed for the grazed leys and the lowest for the cut-used permanent grassland. However, no correlation was found between the highly positive field-Nbalance and the amount of $\mathrm{NO}_{3}$-leached. This indicates a high $\mathrm{N}$ carry-over from grass-clover swards to the subsequent cash crop unit instead of increasing the risk of groundwater contamination from grazed leys in integrated animal crop-systems and underlines the eco-efficiency of dairy farming based on grazed ley systems.
\end{abstract}

Keywords: leys; groundwater; rotational grazing; organic farming; multi-species swards

\section{Introduction}

Dairy systems in northwest Europe strive to increase milk productivity, although the amount of forage land available remains the same. This has led to a land-use intensification in forage production and an increased level of supplementary feed imports at farm-gate, which is often associated with negative environmental effects. This makes the sustainability of confined systems, which are often used, questionable. The farm-nitrogen-balance of dairy systems increased and resulted in the $\mathrm{N}$ leaching to groundwater, which often reaches the critical limit of nitrate $\left(\mathrm{NO}_{3}\right)$ per litre [1]. As an example, in northern Germany, most dairy farms are located on sandy soils due to the existent land-use competition with cashcrops for fertile soils. The water retention capacity of these soils is low and the surplus of 
winter precipitation in these areas means that they are predisposed to substantial $\mathrm{NO}_{3}$ leaching [2], especially when $\mathrm{N}$ is supplied in excess of the plant needs [3]. The majority of $\mathrm{N}$ leached from soils consist of $\mathrm{NO}_{3}$, whilst $\mathrm{NH}_{4}$ is considered to be less important.

Dairy production is therefore considered as one of the main pollutants of $\mathrm{NO}_{3}-\mathrm{N}$ in surface- and groundwater $[4,5]$ which presents a growing concern and an environmental problem [6,7]. This has led to the establishment of the European Union Nitrate Directive [8], the Water Framework Directive [9] and the Groundwater Directive [10] to protect both surface and ground water from $\mathrm{NO}_{3}$ contamination as a consequence of agricultural use. This would also be in accordance with the European Nitrogen Assessment (ENA) which identifies challenges and threats associated with $\mathrm{N}$ pollution [11] while enhancing public awareness regarding how best to approach these challenges as mitigation options. To achieve a more sustainable balance between profitability and the environmental impact effects of dairy farming, an increased urgency exists to focus on adapting current agricultural production systems [12]. The modification of farming practices is required to support reduction strategies in solving environmental problems that are caused by currently followed agricultural practices [13]. Low-input farming systems could serve as a platform to achieve this goal, to ensure adequate production is still achieved while minimizing the negative environmental effects associated with dairy farming practices.

The inclusion of forage herbs in grass-clover swards has been found to encourage a reduction in the environmental impact of milk production [14]. Several other publications support this statement and indicate that the inclusion of legumes and forage herbs in pastures can reduce the impact of milk on the environment $[6,15,16]$. Forage crops in mixed farming systems, also referred to as ley-arable-systems, have traditionally been used in Europe as an additional source of feed for ruminants. Traditionally, organic farming follows the approach of combining livestock and crop production as well as incorporating a high percentage of forage legumes in the crop rotations [17-19]. Increased pressure, as a result of agricultural policies, ensured the integration of these forage crops into arable systems. Moreover, the use of legume-based forage production increases the $\mathrm{N}$ cycling efficiency which leads to lower $\mathrm{N}$ surpluses and less environmental loads of reactive $\mathrm{N}$ [20]. It is possible that the introduction of deep-rooting legumes such as red clover and bird's-foot trefoil (Lotus corniculatus), as well as forage herbs, into a mixture of perennial ryegrass could also help reduce $\mathrm{N}$ leaching. Another method by which to remove $\mathrm{N}$ from the sward is by incorporating silage cuts. The admixture of forage herbs or legumes in pastures can affect the yield performance and agronomic traits positively and can further provide environmental benefits [21].

Ruminant-based ley-arable-systems in the temperate conditions of north-west Europe are considered to be a viable strategy in achieving sustainable intensification [22]. These mixed systems, that are based on grazed leys, have multifunctional benefits including soil carbon sequestration, a prevention of runoff and soil erosion, weed suppression and a reduction in $\mathrm{N}$ leaching [23-25]. However, the introduction of grazing animals into farming systems increases the risk of $\mathrm{N}$ losses as most of the ingested $\mathrm{N}$ from animals is excreted back on to the swards via urine and faeces during grazing $[2,14]$. Urine that is deposited onto pasture can amount to as much as $200-2000 \mathrm{~kg} \mathrm{~N} \mathrm{ha}^{-1}$ [26] which by far exceeds the uptake capacity of plants. If $\mathrm{N}$ is applied in excess of plant needs, it may increase the risk of nitrate leaching and other forms of environmental pollution [3]. Due to poor management, excess $\mathrm{N}$ has become more apparent on farms with high $\mathrm{N}$ inputs. The difference between the $\mathrm{N}$ input and its output in the system can amount to up to $450 \mathrm{~kg} \mathrm{~N} \mathrm{ha}^{-1}$ year $^{-1}$ due to a low level of $\mathrm{N}$ recovery in milk and meat [27]. It has been shown that the use of diverse mixtures in pastures could reduce the $\mathrm{N}$ surplus in forage and, consequently, the $\mathrm{N}$ excretion from animals and can also reduce the extent of $\mathrm{N}$ leaching [28].

Perennial ryegrass (Loliumperenne L.) swards are commonly used for grazing in pasture-based systems. Other pastures can include a mixture of ryegrass-white clover (Trifoliumrepens L.) and/or red clover (Trifoliumpratense L.) swards. Grass leys have been adopted for grazed systems and are beneficial in reducing the environmental effects asso- 
ciated with grazed dairy systems. Under the temperate conditions of northern Germany, multispecies leys can be used to increase its biodiversity without compromising on the forage yield and quality [21]. Grazing systems have also been positively linked to consumer preference $[29,30]$. Grass-based dairy systems are therefore considered to be highly competitive [31] as well as environmentally friendly and economically viable [31,32]. However, the intensification and mismanagement of pastures can increase the rate of nutrient losses and may lead to the imbalance of nutrients in such systems [33]. Moreover, with an increase in the sward age, intensive grazing management may increase the risk of $\mathrm{N}$ surpluses, due to the accumulation of organic $\mathrm{N}$ from faeces only becoming erratically available for plant growth with increasing soil $\mathrm{N}$ during the weeks after excretion [34].

Catch crops are used to retain $\mathrm{N}$ during winter. Moreover, catch crops also have the benefit of providing additional forage. The inclusion of catch crops in ley-arable systems has indicated the role and benefits associated with these cover crops to reduce nutrient losses during winter drainage through the re-capture of $\mathrm{N}$. This is the case if the $\mathrm{N}$ demand of catch crops does not meet the $\mathrm{N}$ supply from the decay of soil organic matter. Catch crops can reduce soil mineral $\mathrm{N}$ from the soil profile and, consequently, the risk of $\mathrm{N}$ leaching losses [35]. This is particularly important in agricultural systems with a low of external $\mathrm{N}$ supply, such as organic farming. The amount of recovered $\mathrm{N}$ from catch crops will depend on the quantity of $\mathrm{N}$ that remains in the soil, the prevailing weather conditions and the length of the growing period [36,37]. Moreover, catch crops can provide additional forage later in the year, at which point the forage yield on the farm decreases due to lower temperatures and radiation. Grazing catch crops late in the year also poses additional risks. An increased $\mathrm{N}$ leaching as a result of trampling patches and the $\mathrm{N}$ excreted from a grazing animal during this period are associated with higher levels of rainfall and wet soil conditions. For this reason, the integration of these catch crops into ley-arable systems needs to be planned and examined in existing grazing rotations to ensure their economic and environmental success.

In the current study we aimed to assess the effects of grazing in a ley-arable-system on groundwater protection. We hypothesize that the combination of highest root length density from perennial ryegrass [38] on the one hand, and the tap root system from red clover and herbs on the other hand, ensure the highest $\mathrm{N}$ uptake efficiency and, as a consequence, the lowest nitrate leaching figures. Thus, we evaluated the extent to which $\mathrm{N}$ leaching occurs under sward ages of differently grazed, diverse mixtures in the context of an on-farm research study in northern Germany. Subsequently, N leaching was measured during winter and compared with cut-used permanent grassland and cover crops cultivated after ley removal as a pre-crop. The results from the current study could provide insight into how best to reduce $\mathrm{N}$ leaching, which would assist in pasture management and in developing mitigation strategies to combat excess reactive $\mathrm{N}$ as a result of dairy farming under temperate climate conditions. Accordingly, in this paper, we present results from field trials over a three-year period. We hypothesize that grass-clover leys ensure low nitrate leaching losses even under intensively grazed conditions.

\section{Materials and Methods}

\subsection{Experimental Site Description}

An on-farm research study was conducted on temporary and permanent grassland sites at the experimental farm of Lindhof ( $54^{\circ} 27^{\prime} \mathrm{N}, 9^{\circ} 57^{\prime} \mathrm{E}, 10$ m.a.s.l.) by the Grass and Forage Science group, Kiel University, Germany. The research farm is located on the Baltic Sea shoreline at the Eckernförde Bay. The area has a temperate oceanic climate with a longterm (1991-2020) mean annual temperature of $9.3^{\circ} \mathrm{C}$ and long-term mean annual rainfall of $754 \mathrm{~mm}$. Historically, the site was used for a five-year crop rotation for arable crops until 1993. Afterwards, it was converted to an organic farming system according to stipulations of the association "Bio-land" (which by definition prohibits the use of chemical fertilizers and pesticides) and some arable fields were converted to permanent grassland concurrently. Beyond these permanent grassland fields, the grazing system on the experimental farm 
could best be described as a two-year grass-clover-ley system in an organic four to five-year crop rotation (2 years of grass-clover; followed by two to three years of crops: oats/winter triticale, faba beans/winter spelt, consecutively). The grass-clover swards are established as an under-storey in the winter spelt. The total farm area is 121 ha comprising of 56 ha for herbage production, where 9 ha are permanent grassland, and 46 ha grass-clover-leys are utilized. The leys were rotationally grazed by 85 Jersey cows. The stocking rates for dairy cows on pastures were adjusted in accordance with the non-destructive aboveground biomass measurements (AGB) that were obtained with a yield-plate-meter to ensure an optimal forage allowance of $1 \mathrm{t}$ DM per ha between one and two grazing days per grazing cycle. They usually have access to the pasture for an average of 292 days per year ${ }^{-1}$ from March to November. Swards which were outside of the range of the milking parlor were cut four times per year to make silage. The grass-clover swards did not receive any additional fertilizer $\mathrm{N}$ with the exception of biological nitrogen fixation (BNF). All cattle manure produced during the winter were used in cereals and for cut-used permanent grassland as well as for catch crops prior to seeding. In the ley-arable system of the experimental farm, catch crops (annual ryegrass) were established on some fields after a cereal harvest and were grazed twice between October and December. Cattle slurry application was applied with trailing hoses. The soil type on the experimental site can be classified as a loamy sand to sandy loam soil. The soil properties were likely comprised of $11 \%$ clay, $29 \%$ silt and $60 \%$ sand with a $1.7 \% \mathrm{C}_{\text {org }}$ in the topsoil $(0-30 \mathrm{~cm})$ [39]. The soil bulk density was $1.53 \mathrm{~g} \mathrm{~cm}^{3}$. The winter period is defined, in this study, as the months spanning December-February, spring as March-May, summer as June-August, autumn as September-November.

\subsection{Experimental Layout and Treatments}

An experiment was conducted on the farm paddocks, to investigate the $\mathrm{NO}_{3}$-leaching losses from different sward ages of grazed leys and grazed catch crops. A cut-used permanent grassland served as the control. The different fields were randomly arranged across the experimental farm during three experimental years $(2017 / 2018 ; 2018 / 2019$ and 2019/2020). The different systems were examined, and information regarding the sward age, grazing interval and slurry fertilization was collected and has been provided in Table 1.

Table 1. Different pasture systems and fertilization levels evaluated in the current field study.

\begin{tabular}{|c|c|c|c|c|c|}
\hline $\mathrm{Nr}$ & System & $\begin{array}{c}\text { Sward Age } \\
\text { (Years) }\end{array}$ & Management & $\begin{array}{c}\text { Fertilization } \\
\left(\mathrm{kg} \mathrm{N} \mathrm{ha}^{-1}\right)\end{array}$ & Abbreviation \\
\hline 1 & \multirow{2}{*}{$\begin{array}{l}\text { permanent } \\
\text { grassland }\end{array}$} & \multirow{2}{*}{$>20$} & \multirow{2}{*}{$4 \times$ silage cuts } & 0 & PG \\
\hline 2 & & & & 240 & PG240N * \\
\hline 3 & \multirow{4}{*}{$\begin{array}{c}\text { grass- } \\
\text { clover- } \\
\text { ley }\end{array}$} & 1 & $5 \times$ silage cuts & 0 & GC 1y \\
\hline 4 & & $0^{* * *}$ & $2 \times$ grazed & 0 & GC 0y \\
\hline 5 & & 1 & \multirow{2}{*}{$\begin{array}{l}8 \times \text { grazed, } 1 \times \\
\text { silage cut }\end{array}$} & 0 & GC 1y grazed \\
\hline 6 & & 2 & & 0 & GC 2y grazed \\
\hline 7 & cover crop & $0 *$ & $2 \times$ grazed & 60 & CC 60N grazed ** \\
\hline
\end{tabular}

${ }^{*}$ applied as cattle slurry in 4 dressings per year. ${ }^{* *}$ applied as cattle slurry in one dressing prior to catch crop seeding. ${ }^{* * *}$ grass-clover under-storey following grain harvest.

\section{3. $\mathrm{NO}_{3}$-Leachate Analysis}

Soil water samples were obtained using ceramic suction cups with a pore size of $1 \mu \mathrm{m}$, $54 \mathrm{~mm}$ in length and a diameter of $20 \mathrm{~mm}$ (Mullit, ecoTech, Bonn, Germany) over the autumn/winter period. The suction cups were installed in the soil at a depth of $75 \mathrm{~cm}$ at a 60-degree vertical angle to minimize the preferential flow. The suction cups were applied to each system, with 12 replicates covering an area of $<0.5$ ha. The suction cups were subject to a vacuum of 0.4 bars to gather free drainage water. Soil water samples were collected weekly from November to March and afterwards water subsamples from three suction 
cups were pooled together into one representing sample (four samples in total for each system and sampling date). Leachate samples were stored at $-20^{\circ} \mathrm{C}$ until the analysis. The soil water samples were photometrically analyzed using a dual-channel continuous flow analyzer (Skalar Analytical Instrument, Breda, The Netherlands) to determine the $\mathrm{NO}_{3}-\mathrm{N}$ concentrations. Only the data for the $\mathrm{NO}_{3}-\mathrm{N}$ fraction, as an indicator of groundwater pollution, was used to calculate the $\mathrm{N}$ leachate because it was by far the main component, and both the $\mathrm{NH}_{4}-\mathrm{N}$ and organic $\mathrm{N}$ only marginally contributed. A climatic water balance model was used to calculate the amount of percolating water by using the (i) weather and soil data gathered from the experimental site (ii) the actual evapotranspiration [40] and (iii) the specific coefficients $[41,42]$ to correct for the evapotranspiration.

\subsection{Forage Yield and Quality}

The forage yield was sampled by cutting the swards prior to grazing. Quadrats with an area of $0.5 \mathrm{~m}^{2}$ were used to make $5 \mathrm{~cm}$ above ground cuttings. Ten quadrat samples of each subplot were randomly cut across the field by hand-operated clippers, collected in a bag and their weight was recorded immediately after harvesting. From the cut samples, two sub-samples of between $80-100 \mathrm{~g}$ were obtained. The first sub-sample was used to determine the dry matter (DM) content and was used for nutrient analyses. The second sub-sample was used for botanical composition and organized into three functional groups (grass, legumes and non-leguminous herbs). Samples were placed in an oven to dry at $60{ }^{\circ} \mathrm{C}$ for $48 \mathrm{~h}$. The DM content and the forage yield ( $\left.\mathrm{kg} \mathrm{DM} \mathrm{ha}{ }^{-1}\right)$ could then be determined. The dried forage samples were milled (Ultra centrifugal mill, ZM200, Retsch $\mathrm{GmbH}$, Haan, Germany) to a particle size of $1 \mathrm{~mm}$ for analyses. The $\mathrm{N}$ content in the herbage was directly determined with an elemental analyzer (Vario Max CN, Elementar Analysensysteme, Hanau, Germany). The total crude protein (CP) was calculated by multiplying the respective $\mathrm{N}$-content with a factor of 6.25. After grazing of the leftovers, the pasture and catch crops were sampled according to the procedure described above to calculate the net-grazing yield.

\subsection{Field-N-Balance}

The field-N-balance $\left(\mathrm{kg} \mathrm{N}^{-1}\right.$ year $\left.^{-1}\right)$ for the different treatments were calculated as the difference between the $\mathrm{N}_{\text {input }}$ and $\mathrm{N}_{\text {output }}$ using the following basic equation:

$$
\text { Field-N-balance }=\mathrm{N}_{\text {input }}-\mathrm{N}_{\text {output }}
$$

where $\mathrm{N}_{\text {input }}$ is the amount of $\mathrm{N}$ applied through animal excreta, slurry application and $\mathrm{BNF}$; and $\mathrm{N}_{\text {output }}$ refers to the amount of $\mathrm{N}$ exported through biomass. The symbiotic $\mathrm{N}_{2}$-fixation of clovers was calculated using the empirical model described in Høgh-Jensen et al. [43]. The model provided by Høgh-Jensen includes the following parameters: sward age, sward composition and management.

\subsection{Weather Data and Water Drainage}

Weather data during the experimental years were recorded by a weather station (Vantage Pro2, Davies Instruments Corp., Hayward, CA, USA) close to the experimental sites $(<1 \mathrm{~km})$. The weather conditions during the study period (2017-2020) were contrasted between the years and they are presented in Table 2 . The mean monthly rainfall for the study period was $59 \pm 4.3 \mathrm{~mm}$ compared to the long-term average of $63 \pm 3.8 \mathrm{~mm}$. The winter leaching period (referred to here as October until March) of 2018/2019 received $298 \mathrm{~mm}$ of precipitation which was $82 \mathrm{~mm}$ less than compared to the long-term average of $380 \mathrm{~mm}$, therefore it was considered to be a dry winter compared to the long-term average. The monthly average temperatures recorded during the study period ranged from -0.9 to $19.8^{\circ} \mathrm{C}$ with an average of $10.2 \pm 0.8^{\circ} \mathrm{C}$ compared to the long-term average of $9.3 \pm 1.7^{\circ} \mathrm{C}$ [44]. 
Table 2. Monthly precipitation and average temperatures during the study period compared to the long-term total precipitation and average temperature (1991-2020) [44].

\begin{tabular}{|c|c|c|c|c|c|c|c|c|c|c|c|c|c|}
\hline Year & January & February & March & April & May & June & July & August & September & October & November & December & Total \\
\hline \multicolumn{14}{|c|}{ Precipitation (mm) } \\
\hline 2017 & 80 & 57 & 51 & 47 & 42 & 116 & 102 & 61 & 75 & 124 & 91 & 82 & 928 \\
\hline 2018 & 96 & 23 & 45 & 74 & 24 & 32 & 8 & 66 & 39 & 40 & 20 & 64 & 531 \\
\hline 2019 & 41 & 39 & 94 & 22 & 61 & 74 & 54 & 48 & 100 & 85 & 79 & 49 & 746 \\
\hline 2020 & 80 & 130 & 36 & 14 & 26 & 60 & 79 & 62 & 12 & 61 & 17 & 60 & 637 \\
\hline Long-term & 67 & 51 & 52 & 38 & 50 & 64 & 83 & 78 & 62 & 74 & 65 & 71 & 754 \\
\hline \multicolumn{14}{|c|}{ Temperature $\left({ }^{\circ} \mathrm{C}\right)$} \\
\hline 2017 & 1.3 & 2.8 & 6.5 & 7.2 & 13.3 & 16.3 & 16.7 & 16.9 & 13.9 & 12.0 & 6.3 & 4.2 & 9.8 \\
\hline 2018 & 3.4 & -0.2 & 1.7 & 9.8 & 14.8 & 16.8 & 19.8 & 18.6 & 14.6 & 11.5 & 6.4 & 5.2 & 10.2 \\
\hline 2019 & 2.1 & 5.2 & 6.4 & 8.6 & 10.6 & 17.9 & 17.3 & 18.4 & 14.0 & 10.8 & 6.2 & 5.2 & 10.2 \\
\hline 2020 & 5.7 & 5.7 & 5.6 & 9.0 & 11.2 & 16.6 & 15.8 & 19.7 & 14.8 & 11.3 & 7.9 & 4.4 & 10.6 \\
\hline Long-term & 1.7 & 2.2 & 4.3 & 8.1 & 12.0 & 15.3 & 17.8 & 17.6 & 14.3 & 10.0 & 5.8 & 2.9 & 9.3 \\
\hline
\end{tabular}

The accumulated percolating water that was calculated according to climatic water balance (see Section 2.3) over the duration of the current study is shown in Figure 1. In the second winter period (2018/2019), due to lower precipitation, the amount of percolating water was noticeably below the long-term average amount. The levels of precipitation in the winters of 2017/2018 and 2019/2020 were slightly higher compared with the long-term average. This will have a possible effect on nitrate loads due to the vertical movement of water. For this study, the weather conditions in the first and third winter could strongly increase the risk of N-leaching.

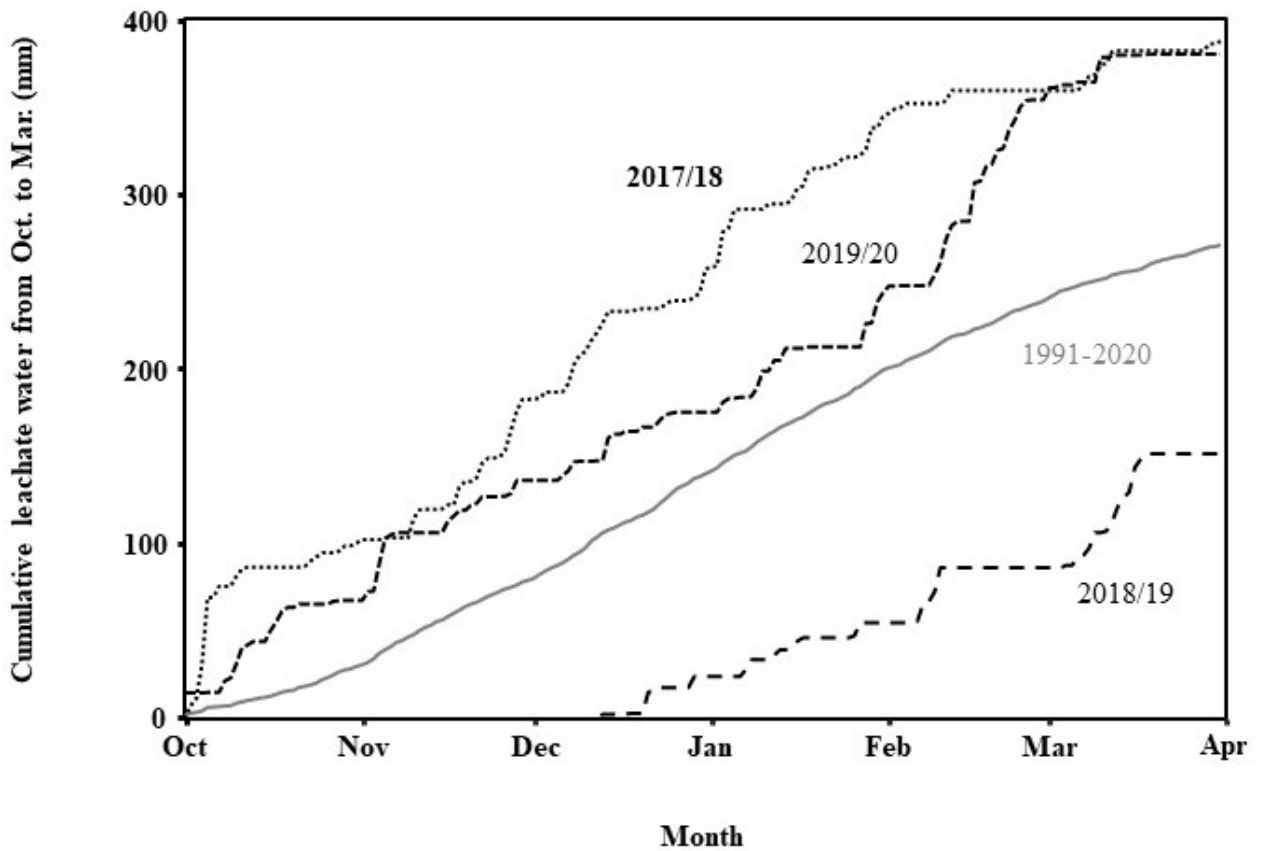

Figure 1. Accumulated percolating water $\left(\mathrm{mm}\right.$ per $\left.\mathrm{m}^{2}\right)$ over the three winter leachate periods (2017/2018, 2018/2019 and 2019/2020) compared to the long-term (1991-2020).

\subsection{Statistical Analyses}

The statistical software R 4.0.3 [45] was used to evaluate the data. The data evaluation started by defining an appropriate statistical linear model. Data distribution was assumed to be normal and heteroscedastic according to the different soil cultivation and fertilization treatments. These assumptions were based on a visual graphical residual analysis [46]. The statistical model included the selected System (S) and the experimental year $(\mathrm{Y})$ as 
well as their interaction term as fixed factors. The significance of factors was declared at $p<=0.05$. Based on this model, an analysis of variance (ANOVA) was conducted to test the hypothesis of the experiment. Furthermore, multiple contrast tests (e.g., see Bretz et al. [46]) were implemented in order to compare the several levels of the tested treatments. In order to evaluate a mathematical relationship between the $\mathrm{N}$ balance and $\mathrm{NO}_{3}$-leaching, simple mathematical regressions were performed.

\section{Results}

\subsection{Nitrogen Leaching}

The $\mathrm{NO}_{3}$-concentration in leachates $\left(\mathrm{mg} \mathrm{L}^{-1}\right)$ and the $\mathrm{N}$ load $\left(\mathrm{kg} \mathrm{NO}_{3}-\mathrm{N} \mathrm{ha}^{-1}\right)$ to ground- or drainage water were affected by the system $(p<0.001)$. An interaction was also observed between the system and experimental year $(p<0.001)$ and is presented in Table 3.

Table 3. Levels of significance among the tested factors: Systems (S), experimental year (Y) and the interaction $(\mathrm{S} \times \mathrm{Y})$.

\begin{tabular}{ccccc}
\hline Factor & $\mathrm{NO}_{3}$-Conc. & $\mathrm{NO}_{3}$-Leaching & N-Yield & N-Balance \\
\hline $\mathrm{S}$ & $* * *$ & $* * *$ & $* * *$ & $* * *$ \\
\hline $\mathrm{Y}$ & n.s. & n.s. & $* * *$ & $* *$ \\
\hline $\mathrm{S} \times \mathrm{Y}$ & $* * *$ & $* * *$ & $* * *$ & $* *$ \\
\hline
\end{tabular}

${ }^{* * *}: p<0.001,{ }^{* *}: p<0.01$.

The nitrate concentration and leaching loads over the trial period (2017/2018, 2018/2019 and 2019/2020) for the different systems are presented in Figure 2. The highest nitrate leaching was observed for the sward types GC_2y_grazed and CC60N_grazed, which occurred during winters 2017/18 and 2019/20 and reached nitrate losses of $\sim 28 \mathrm{~kg} \mathrm{NO}_{3}-\mathrm{N} \mathrm{ha}^{-1}$. The lowest nitrate leaching across the different sward types were observed during the winter of 2018/2019 and ranged between $1.3 \pm 0.2$ and $9.8 \pm 2.4 \mathrm{~kg} \mathrm{NO}_{3}-\mathrm{N} \mathrm{ha}^{-1}$. The highest nitrate losses of $28.7 \pm 3.1 \mathrm{~kg} \mathrm{NO}_{3}-\mathrm{N} \mathrm{ha}^{-1}$ year $^{-1}$ occurred in the GC_2y_grazed sward during year 2017/18, but during the second (2018/2019) and third (2019/2020) years it differed and was much lower at $4.0 \pm 0.6$ and $17.1 \pm 1.7 \mathrm{~kg} \mathrm{NO}_{3}-\mathrm{N} \mathrm{ha}^{-1}$ year ${ }^{-1}$, respectively. The lowest nitrate losses occurred in year 2018/2019 with $1.3 \pm 0.2 \mathrm{~kg} \mathrm{NO}_{3}-\mathrm{N} \mathrm{ha}^{-1}$ year $^{-1}$ leached in the GC_0y sward (Figure 2).

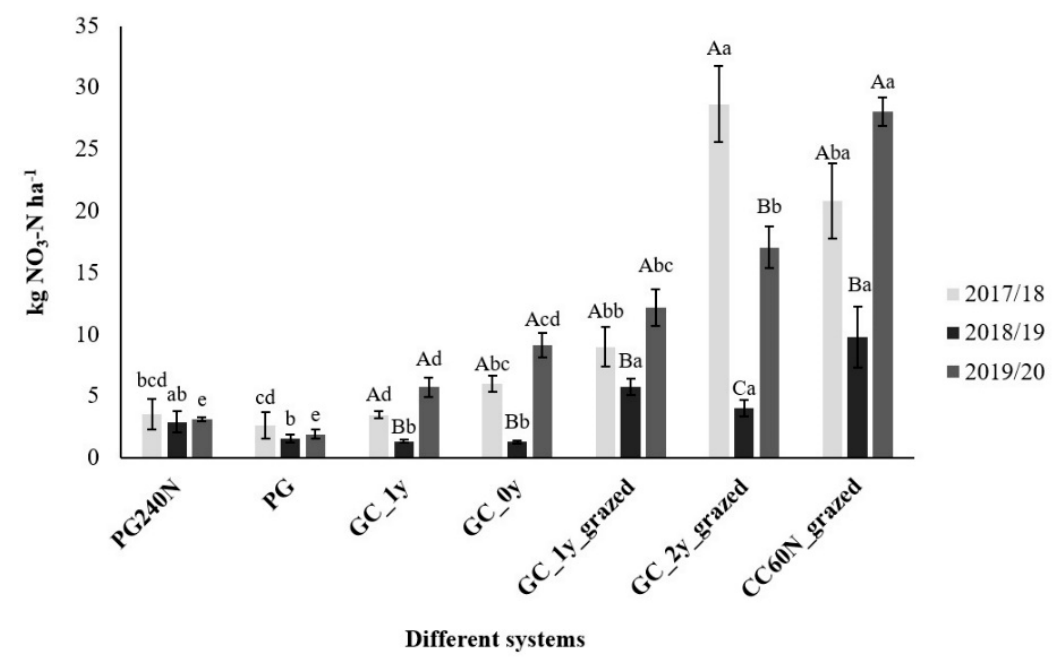

Figure 2. Average nitrate leaching losses $\left(\mathrm{kg} \mathrm{NO}_{3}-\mathrm{N} \mathrm{ha}^{-1}\right)$ of the different systems investigated over three experimental years (2017/2018, 2018/2019 and 2019/2020). Different upper-case letters indicate significant inter-annual differences. Different lower-case letters indicate significant differences between the various sward types. Standard errors are shown. 
The level of nitrate leaching losses differed markedly between the winter of 2018/2019 compared to the winter periods of $2017 / 2018$ and $2019 / 2020$. The mean cumulative nitrate leachate amounts averaged $8.5 \pm 1.8 \mathrm{~kg} \mathrm{NO}_{3}-\mathrm{N} \mathrm{ha}^{-1}$ over the trial period. The CC60N_grazed sward type showed average cumulative $\mathrm{NO}_{3}-\mathrm{N}$ losses over the study period of $19.6 \pm 5.3 \mathrm{~kg} \mathrm{NO}_{3}-\mathrm{N} \mathrm{ha}^{-1}$. In the permanent grassland (PG), lowest cumulative $\mathrm{NO}_{3}-\mathrm{N}$ losses were recorded as $2.1 \pm 0.3 \mathrm{~kg} \mathrm{NO}_{3}-\mathrm{N} \mathrm{ha}^{-1}$. Apart from the total nitrate losses, the $\mathrm{NO}_{3}-\mathrm{N}$ concentration in the soil water is provided in Figure 3. The $\mathrm{NO}_{3}-\mathrm{N}$ concentration ranged between 0.5 and $7.4 \mathrm{mg} \mathrm{L}^{-1}$ during the leachate periods and were found to be higher in the CC60N_grazed compared to PG. Regarding the three-year average only the CC60N treatment exceeded the WHO threshold (5.6 mg NO $3-\mathrm{N} ; 25 \mathrm{mg} \mathrm{NO}_{3}$ ).

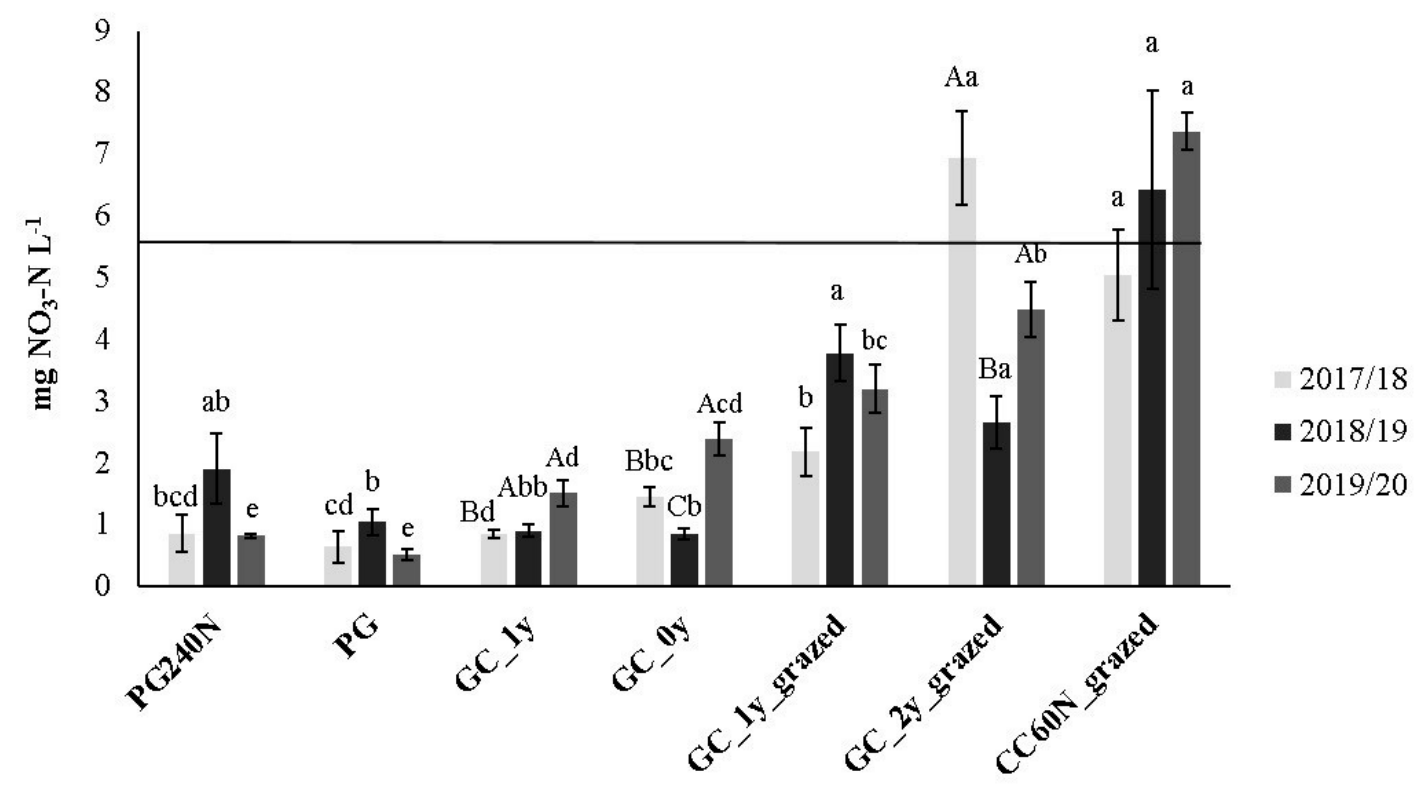

Different systems

Figure 3. Average nitrate concentration in the soil water $\left(\mathrm{mg} \mathrm{L}^{-1}\right)$ of the different systems investigated over three winter leachate periods $\left(2017 / 2018,2018 / 2019\right.$ and 2019/2020). The solid line indicates the threshold of $5.6 \mathrm{mg} \mathrm{NO}_{3}-\mathrm{N} \mathrm{L}^{-1}$. Different upper-case letters indicate significant inter-annual differences. Different lower-case letters indicate significant differences between the various sward types. Standard errors are shown.

\subsection{Herbage and Nitrogen Yield}

The herbage yields for the different systems over the three years of study are shown in Figure 4. Inter-annual differences as well as differences between swards were observed $(p<0.05)$. The herbage yield was in the range of 0.9 to $12.4 \mathrm{t} \mathrm{DM} \mathrm{ha}^{-1}$ over the three-year study period and was measured for the GC_0y (year 2017) and GC_1y_grazed (year 2019), respectively. The average values between the different swards ranged between $1.4 \pm 0.1$ (CC60N_grazed) to $11.0 \pm 0.6$ (GC_1y_grazed) $\mathrm{t} \mathrm{DM} \mathrm{ha}^{-1}$. The average herbage yields were $6.4 \pm 0.6,8.2 \pm 1.2$ and $1.4 \pm 0.1 \mathrm{t} \mathrm{DM} \mathrm{ha}^{-1}$ for the permanent grasslands, grass-clover swards and the cover crop, respectively.

The N-yields of the different systems over the study period (2017-2019) are shown in Table 4. Inter-annual differences as well as differences between the swards were observed $(p<0.05)$. The $\mathrm{N}$-yields were in the range of $181 \pm 51$ and $228 \pm 66 \mathrm{~kg} \mathrm{~N} \mathrm{ha}^{-1}$ during the study period. The years 2017 and 2019 were comparable with an average $\mathrm{N}$-yield of $\sim 220 \mathrm{~kg} \mathrm{~N} \mathrm{ha}^{-1}$ over the different sward types. The lowest N-yield $\left(40.6 \mathrm{~kg} \mathrm{~N} \mathrm{ha}^{-1}\right)$ was observed in the CC60N_grazed swards and the highest $\left(393.9 \mathrm{~kg} \mathrm{~N}^{-1}\right)$ in the GC_1y_grazed swards. The grazed grass-clover swards had an average of $378 \pm 24 \mathrm{~kg} \mathrm{~N}^{-1}$ compared to the non-grazed grass-clover swards with $169 \pm 57 \mathrm{~kg} \mathrm{~N}^{-1}$, with the latter being comparable to the N-yields of $168 \pm 18 \mathrm{~kg} \mathrm{~N} \mathrm{ha}^{-1}$ from the permanent grasslands. 


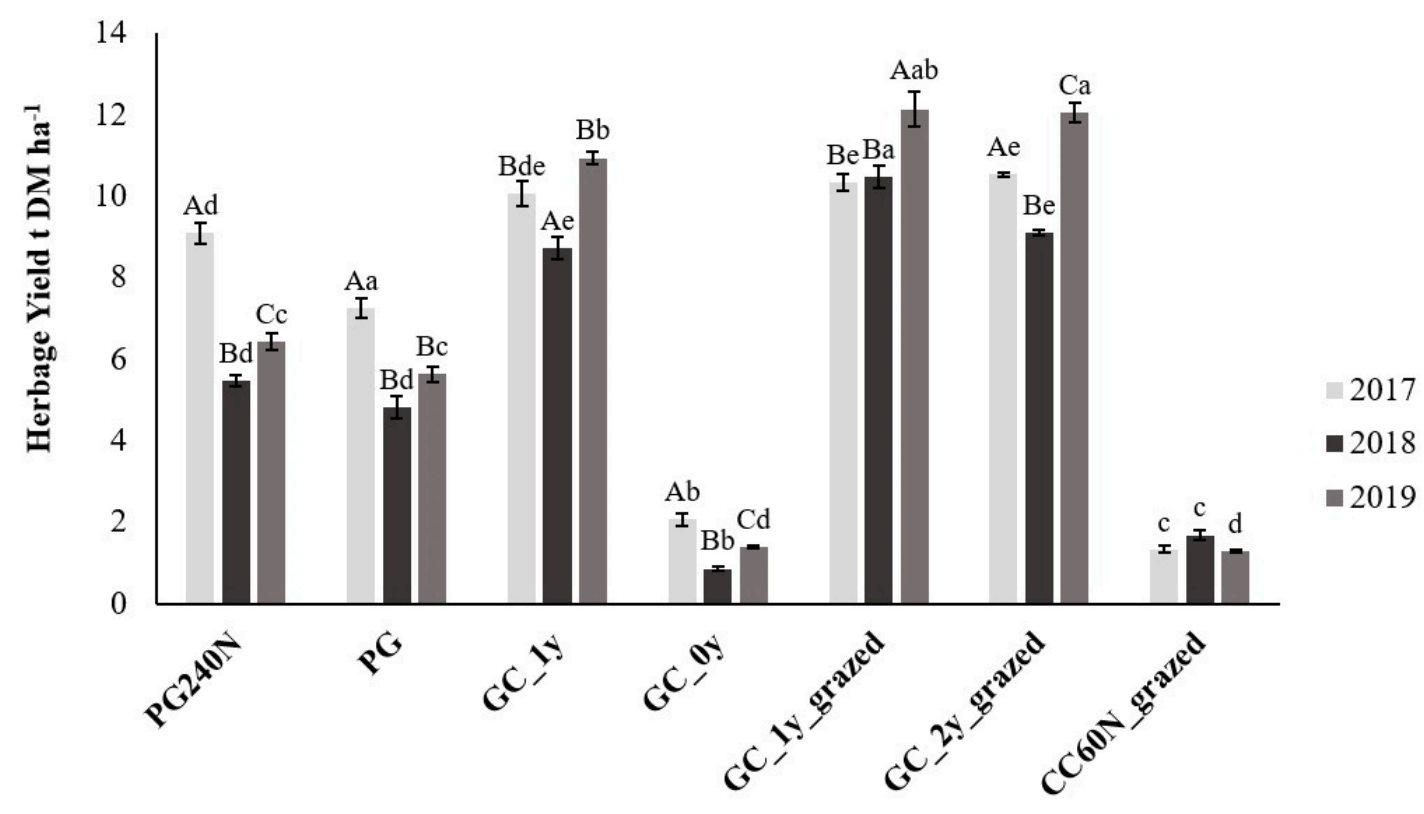

Different systems

Figure 4. Average herbage yield (t DM ha $\left.{ }^{-1}\right)$ of the different sward types investigated over the three years $(2017,2018$ and 2019). Different upper-case letters indicate significant inter-annual differences. Different lower-case letters indicate significant differences between the various sward types.

Table 4. The N-yields ( $\mathrm{kg} \mathrm{N} \mathrm{ha}^{-1}$ ) of the different sward types investigated over the three years (2017, 2018 and 2019). Different upper-case letters indicate significant inter-annual differences. Different lower-case letters indicate significant differences between the various sward types. SEM are shown in brackets.

\begin{tabular}{cccccccc}
\hline \multirow{2}{*}{ Year } & PG240N & PG & GC 1y & GC_0y & $\begin{array}{c}\text { GC 1y } \\
\text { Grazed }\end{array}$ & $\begin{array}{c}\text { GC 2y } \\
\text { Grazed }\end{array}$ & $\begin{array}{c}\text { CC 60N } \\
\text { Grazed }\end{array}$ \\
\cline { 2 - 7 } & \multicolumn{7}{c}{ N-Yield (kg N ha ${ }^{-1}$ ) } \\
\hline \multirow{2}{*}{2017} & $229.5^{\mathrm{Acd}}$ & $214.0^{\mathrm{Ad}}$ & $285.5^{\mathrm{c}}$ & $63.7^{\mathrm{Aa}}$ & $362.4^{\mathrm{Be}}$ & $363.7^{\mathrm{Ae}}$ & $36.9^{\mathrm{b}}$ \\
& $(12.6)$ & $(7.3)$ & $(13.1)$ & $(4.8)$ & $(1.2)$ & $(6.1)$ & $(1.9)$ \\
\hline \multirow{2}{*}{2018} & $122.7^{\mathrm{Bd}}$ & $123.4^{\mathrm{Bd}}$ & $288.8^{\mathrm{e}}$ & $23.9^{\mathrm{Bb}}$ & $378.4^{\mathrm{Ba}}$ & $284.6^{\mathrm{Be}}$ & $4^{\mathrm{B}}$ \\
& $(5.3)$ & $(10.3)$ & $(8.7)^{\mathrm{c}}$ & $(2.0)$ & $(8.8)$ & $(10.1)$ & $(2.9)$ \\
\hline \multirow{2}{*}{2019} & $160.2^{\mathrm{Cb}}$ & $159.0^{\mathrm{Bb}}$ & $316.4^{\mathrm{a}}$ & $38.8^{\mathrm{Cd}}$ & $440.8^{\mathrm{Ac}}$ & $443.0^{\mathrm{Cc}}$ & $38.5^{\mathrm{d}}$ \\
& $(9.2)$ & $(9.2)$ & $(2.9)$ & $(1.5)$ & $(16.0)$ & $(8.9)$ & $(0.7)$ \\
\hline
\end{tabular}

\subsection{Nitrogen Balance}

The calculated field-N-balances were positive in all different swards over the study period. Field-N-balances varied widely between different sward types, ranging from $11 \pm 4$ to $276 \pm 21 \mathrm{~kg} \mathrm{~N} \mathrm{ha}^{-1}$ and are displayed in Table 5 . The values were generally lower for the permanent grassland (PG) compared to the permanent grassland that received slurry (PG240N) and were $11 \pm 4$ compared to $149 \pm 8 \mathrm{~kg} \mathrm{~N}^{-1}$, respectively. The highest average field-N-balance of $210 \pm 37 \mathrm{~kg} \mathrm{~N} \mathrm{ha}^{-1}$ were observed in the grazed grass-clover swards compared to the grass-clover swards that were not grazed, with a field-N-balance of $57 \pm 13 \mathrm{~kg} \mathrm{~N} \mathrm{ha}^{-1}$. 
Table 5. The N-balance of the different sward types investigated over the three years (2017, 2018 and 2019). Different upper-case letters indicate significant inter-annual differences. Different lower-case letters indicate significant differences between the various sward types. SEM are shown in brackets.

\begin{tabular}{|c|c|c|c|c|c|c|c|}
\hline & PG240N & PG & GC 1y & GC $0 y$ & $\begin{array}{l}\text { GC 1y } \\
\text { Grazed }\end{array}$ & $\begin{array}{l}\text { GC 2y } \\
\text { Grazed }\end{array}$ & $\begin{array}{l}\text { CC } 60 N \\
\text { Grazed }\end{array}$ \\
\hline \multicolumn{8}{|c|}{ Yearly Inputs (kg N ha ${ }^{-1}$ ) } \\
\hline 2017 & $355.5(5.7)$ & $222.8(8.5)$ & $383.5(18.9)$ & $58.0(5.1)$ & $379.1(12.2)$ & $277.9(5.1)$ & $60.0 *$ \\
\hline 2018 & $278.9(3.0)$ & $121.6(9.5)$ & $358.7(26.0)$ & $24.6(3.1)$ & $374.2(18.7)$ & $159.0(11.9)$ & $60.0 *$ \\
\hline 2019 & $305.7(4.8)$ & $165.3(9.5)$ & $404.0(5.8)$ & $38.6(1.3)$ & $479.1(19.5)$ & $373.2(3.4)$ & $60.0 *$ \\
\hline \multicolumn{8}{|c|}{ Yearly Outputs $\left(\mathrm{kg} \mathrm{N} \mathrm{ha}^{-1}\right)$} \\
\hline 2017 & $221.8^{\mathrm{Ae}}(12.2)$ & $206.7^{\mathrm{Ae}}(7.0)$ & $285.5^{\text {a }}(13.1)$ & $17.6^{\mathrm{Ab}}(1.3)$ & $118.4^{\mathrm{Bd}}(1.4)$ & $123.7^{\mathrm{Ad}}(2.9)$ & $10.3^{c}(0.5)$ \\
\hline 2018 & $118.5^{\mathrm{Be}}(5.1)$ & $119.2^{\text {Bde }}(10.0)$ & $288.8^{\mathrm{c}}(8.7)$ & $6.6^{\mathrm{Ba}}(0.6)$ & $125.8^{\mathrm{Be}}(5.2)$ & $95.4^{\mathrm{Bd}}(4.4)$ & $12.9^{\mathrm{b}}(0.8)$ \\
\hline 2019 & $153.3^{\text {Cc }}(9.8)$ & $150.9^{\mathrm{Bc}}(10.1)$ & $316.4^{\mathrm{a}}(2.9)$ & $10.8^{\mathrm{Cb}}(0.4)$ & $161.2^{\mathrm{Ac}}(5.9)$ & $159.4^{\mathrm{Cc}}(2.9)$ & $10.7^{\mathrm{b}}(0.2)$ \\
\hline \multicolumn{8}{|c|}{$\mathrm{N}$-balance (Inputs-Outputs) (kg N ha $\left.{ }^{-1}\right)$} \\
\hline 2017 & $133.7^{\text {Acd }}(8.3)$ & $15.8^{\mathrm{b}}(4.1)$ & $98.0^{\mathrm{c}}(8.3)$ & $40.4^{\mathrm{Ae}}(3.9)$ & $260.7^{\mathrm{Ba}}(11.8)$ & 154. Ad $^{\text {Ad.0) }}$ & $49.7^{\mathrm{e}}(0.5)$ \\
\hline 2018 & $160.4^{\mathrm{Bb}}(2.2)$ & $2.4^{\mathrm{d}}(4.9)$ & $69.9^{\text {ce }}(19.0)$ & $17.9^{\mathrm{Bcd}}(2.5)$ & $248.4^{\mathrm{Ba}}(14.7)$ & $63.7^{\mathrm{Be}}(7.7)$ & $47.1^{\mathrm{e}}(0.8)$ \\
\hline 2019 & $152.3^{\mathrm{Abd}}(7.3)$ & $14.4^{\mathrm{b}}(2.5)$ & $87.6^{\mathrm{c}}(8.7)$ & $27.8^{\mathrm{Cf}}(0.9)$ & $317.9^{\text {Аa }}(13.9)$ & $213.8^{\mathrm{Ce}}(4.6)$ & $49.3^{g}(0.2)$ \\
\hline
\end{tabular}

The field-N-balance was used to investigate the effect of different management systems on N-leaching. The correlation between the field- $\mathrm{N}$-input and the $\mathrm{NO}_{3}-\mathrm{N}$-losses are shown in Figure 5. A clear relationship was not found between the field- $\mathrm{N}$-input and the $\mathrm{NO}_{3}-\mathrm{N}-\mathrm{losses}$.

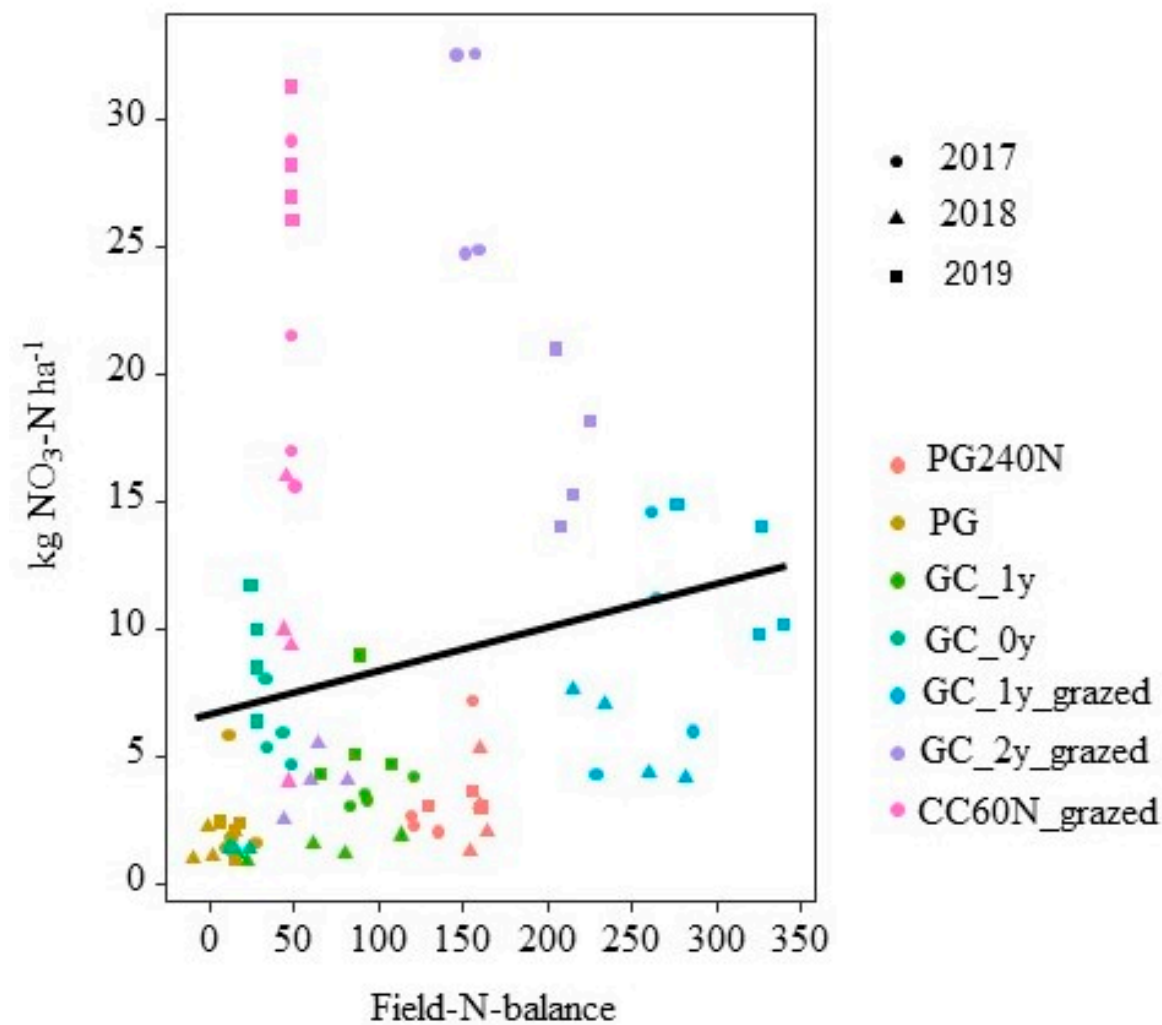

Figure 5. The relationship between the field-N-balance and $\mathrm{NO}_{3}$-leaching $\left(\mathrm{kg} \mathrm{NO}_{3}-\mathrm{N} \mathrm{ha}^{-1}\right)$ of the different systems used in the study. 


\section{Discussion}

\subsection{Nitrogen Leaching Losses}

Nitrate leaching following the swards in the current study may be generally divided into two groups: (1) low leaching $\left(<10 \mathrm{~kg} \mathrm{~N} \mathrm{ha}^{-1}\right)$ consisting of the permanent grasslands (PG, PG240N) and grass-clover swards (GC_1y, GC_0y and GC_1y_grazed), and (2) medium leaching (10-20 kg N ha ${ }^{-1}$ ) consisting of a grass-clover sward and a catch crop which were both under grazing (GC_2y_grazed and CC60N_grazed). The amount of N-leaching depends on the mineral nitrogen access, land-use, soil type as well as the prevailing weather conditions and the length of the growing period [37,47]. It is clear from the results that 2018/19 had less precipitation compared to the other years which resulted in substantially lower amounts of $\mathrm{N}$ leached during this winter (Figure 2). The results from the current study are considered to be low as compared to various European studies that had values between 15 and $50 \mathrm{~kg} \mathrm{NO}_{3}-\mathrm{N} \mathrm{ha}^{-1}$ year $^{-1}[2,48]$.

Silage cuts were obtained from swards (PG, PG240N and GC_1y) and used to feed cows during winter. This allows for the $\mathrm{N}$ to be removed in herbage and fed off-site which avoids $\mathrm{N}$ returns to pasture by avoiding any grazing in situ $[2,47,49]$. This decreases the risk of $\mathrm{NO}_{3}-\mathrm{N}$ leaching losses over the winter period. Cutting-only systems would be the most advantageous in terms of $\mathrm{NO}_{3}-\mathrm{N}$ leaching, however, combining cutting and grazing is a preferred technique to pure grazing systems [2,50]. Our results support this and indicated the $\mathrm{NO}_{3}-\mathrm{N}$ leaching losses to be lower in the permanent grasslands compared to the combined cutting and grazing and mostly grazed swards (PG, PG240N < GC_1y, GC_0y < GC_1y_grazed, GC_2y_grazed, CC60N_grazed). This agrees with a study conducted by Kunrath et al. [47] where the amplitude on nitrate concentrations was lower for grassland.

Intensive tillering as a result of management allows for new root development which assists in nutrient uptake. A well-established root system can contribute considerably to $\mathrm{N}$ uptake which affects the rate of $\mathrm{N}$ losses to the environment [47]. Even though the permanent grassland (PG240N) received fertilizer $\left(240 \mathrm{~kg} \mathrm{~N} \mathrm{ha}^{-1}\right)$, the fertilization did not cause significant increases of $\mathrm{NO}_{3}-\mathrm{N}$ losses. This indicates that these swards ( $>20$ years) are well established with a healthy root system which perform their function to absorb nutrients. Furthermore, roots are key components of $C$ sequestration due to their longer residence time in soils [51].

The grass-clover-leys in the first year of production (GC_1y) contained the lowest $\mathrm{NO}_{3}-\mathrm{N}$ losses compared to the other grass-clover-leys (GC_0y, GC_1y_grazed and GC_2y_grazed) from this study. The $\mathrm{N}$ cycle is generally closed in the short-term while these swards still grow, and during the first year in particular, they invest high amounts of nitrogen into the rooting system. Chen et al. [38] demonstrated, for the same site, fBNPP values of 0.4 , indicating that $40 \%$ of the total DM and nitrogen uptake of swards are stored in the rooting system, resulting in an additional $\mathrm{C}$ storage and $\mathrm{N}$ storage of 1000 and $100 \mathrm{~kg}$ per year, respectively [39], therefore $\mathrm{N}$ leaching is very low. Moreover, leys were established after cereal production that received extensive N-fertilization, which caused a low N-status in the soil. This was also observed in the current study in the swards which were newly established (data not shown). Furthermore, grass-clover-leys can have several and contrasting effects on $\mathrm{NO}_{3}-\mathrm{N}$ leaching losses. Even though BNF can be a major source of $\mathrm{N}$ for crops, it can also add to soil fertility and subsequently lead to $\mathrm{NO}_{3}-\mathrm{N}$ leaching losses [52]. This was also observed in the current study especially when the swards are subjected to additional $\mathrm{N}$-inputs from grazing animals in the second ley year. This is also in accordance with data from Chen et al. [38] who indicated that fBNPP values are much higher in the first (0.6) than in the second (0.4) production year. It is therefore very likely that the $\mathrm{N}$ uptake capacity of the rooting system is reduced from the second production year onwards.

The risk for nitrogen leaching increased through grazing and was highest in the grazed swards due to animal excreta-N when compared to cut-only swards. Large volumes of urine are deposited back onto pasture during grazing which can be greater than the 
capacity of pasture plants to assimilate [26]. Dairy cows metabolize less than $\sim 25 \%$ of their N-intake into milk output and can excrete as much as $\sim 75 \%$ [53]. Therefore, excess $\mathrm{N}$ can accumulate in the soil during autumn, which typically leads to higher N-leaching losses during surplus winter precipitation. This was shown in the cover crop sward under grazing conditions and fertilization $\left(60 \mathrm{~kg} \mathrm{Nha}^{-1}\right.$ before sowing in August).

The inclusion of forage legumes in pasture mixtures can reduce the environmental impact of milk production by supplying additional $\mathrm{N}$ via $\mathrm{BNF}$ and thereby reducing $\mathrm{N}$-leaching through more effective $\mathrm{N}$-cycling in these forage legume systems $[15,17,19]$. However, a clover-N feedback mechanism exists whereby the proportion of legumes and consequently BNF decreases in grass-legume swards when $\mathrm{N}$ inputs increases $[48,54]$. For this reason, there will be a lower input from BNF when $\mathrm{N}$ inputs from excreta occur. This was also the case in the current study which had a lower clover contribution in the swards that were under grazing. Higher $\mathrm{N}$ leaching losses were observed in the current study from grazed grass-clover-leys (on average $8.98 \mathrm{~kg} \mathrm{NO}_{3}-\mathrm{N}^{-1}$ ) compared to the non-grazed grass-clover-leys (on average $3.53 \mathrm{~kg} \mathrm{NO}_{3}-\mathrm{N} \mathrm{ha}^{-1}$ ). This could be explained by a reduction in BNF in the grazed grass-clover-leys as a consequence of recycled animal excreta. Furthermore, the introduction of deep-rooting legumes such as red clover and bird 's-foot trefoil (Lotus corniculatus) into perennial ryegrass swards has a further potential to reduce N-leaching. However, the red clover contribution declined with sward age (second ley year) as a result of its lower grazing tolerance compared with white clover.

Jersey cows grazed the swards in the current study on the research site. The currently implemented grazing strategies rely on a lower herbage $\left(1 \mathrm{tha}^{-1}\right)$ and between $8-10$ grazing cycles compared with grazing strategies in the 1990s which contained higher herbage and provided fewer grazing cycles. On one hand, this suggests that much more urine- $\mathrm{N}$ is evenly excreted onto pasture over the grazing period and on the other hand, that the nitrogen uptake capacity of the swards is enhanced [55]. Jersey cows are often seen as more environmentally friendly compared to Holstein cows as they excrete less nutrients in urine per urination [56,57]. Nonetheless, this might explain the higher N-leaching in the grass-clover-ley in the second year of production due to a decrease in clover contribution to the sward due to increased $\mathrm{N}$ from urine. However, N-leaching values from the current study are still very low compared to the published data from northern Germany for the silage maize systems, which represents forage production for a high input-high output dairy system [58], suggesting that even though excreta affect the rate of N-leaching losses, it was still lower than the crop demand.

The risk associated with $\mathrm{N}$-leaching depends on the rate of mineralization and the successful uptake of $\mathrm{N}$ by the following crop [48]. Catch crops have been shown to be effective at reducing N-leaching losses $[36,49,59]$. However, a catch crop needs to be established early enough to absorb a considerable amount of $\mathrm{N}$ before leaching begins in winter. The results from the current study indicated that the cover crop under grazing and fertilization had the highest amount of N-leaching losses. However, even with the highest amount of $\mathrm{N}$-leaching $\left(\sim 20 \mathrm{~kg} \mathrm{NO}_{3}-\mathrm{N} \mathrm{ha}^{-1}\right)$ compared to the other swards from this study, this level is still below other values reported in the literature $\left(10-80 \mathrm{~kg} \mathrm{NO}_{3}-\mathrm{N} \mathrm{ha}^{-1}\right)$ which places our findings at the lower end [1,48,52]. The advantage in reducing $\mathrm{NO}_{3}-\mathrm{N}$ leaching losses is derived in high $\mathrm{N}$ removal in herbage and low $\mathrm{N}$ loads recycled from cow excreta [48]. Additional mitigation could be achieved through the biomass harvesting of catch crops instead of grazing by animals. Furthermore, even though regional services suggest extensive $\mathrm{N}$-fertilization of catch crops prior to seeding or shortly after succeeding cereal crops, the fertilization of grazed catch crops should be reconsidered because of the high level of $\mathrm{N}$ losses.

Field management should focus on increasing the $\mathrm{N}$ uptake during autumn to decrease $\mathrm{N}$-leaching losses during winter [35,52]. High mineral $\mathrm{N}$ and mineralization of residues at the end of the vegetation period should be avoided. The potential N-leaching can be reduced by establishing catch crops earlier, but its benefits vary and depend on the weather 
conditions [35]. However, $\mathrm{N}$-leaching can increase with the continuous use of catch crops when winter cereals cover the soil during winter and autumn [52].

\subsection{Field-N-Balance}

The only information that is often available at the field-, farm- and regional level, is the field$\mathrm{N}$-balance which is then used to estimate risks associated with N-leaching. The field-N-balance was positive in all the different swards and ranged between 11 and $150 \mathrm{~kg} \mathrm{~N} \mathrm{ha}^{-1}$ year $^{-1}$. These values are considerably less than values $\left(150-250 \mathrm{~kg} \mathrm{~N} \mathrm{ha}^{-1}\right.$ year $^{-1}$ ) previously reported for the Netherlands and Germany [60], with the exception of the grazed grass-clover sward (GC_2y_grazed) in the current study with a field-N-balance of $276 \mathrm{~kg} \mathrm{~N} \mathrm{ha}^{-1}$ year $^{-1}$.

The field-N-balance was especially high in the grazed grass-clover swards due to direct deposition of animal excreta and only one removal of $\mathrm{N}$ via harvested biomass. This was in accordance with Eriksen et al. [48] who reported the highest amount of surplus $\mathrm{N}$ on grazed plots. The high soil-N status as a result of high $\mathrm{N}$ inputs in the grazing management systems may explain the high $\mathrm{N}$ contents in the grazed grass-clover swards [61]. The presence of clovers can increase $\mathrm{N}$ yields significantly compared to only grasses [62]. Additionally, frequent grazing and biomass cuts can also increase $\mathrm{N}$ fixation which leads to high $\mathrm{N}$ inputs [63]. The grass-clover swards, which were not subjected to grazing and therefore did not display high $\mathrm{N}$ returned through excreta, possessed a low associated field-N-balances of 85 and $29 \mathrm{~kg} \mathrm{~N}^{-1}$ year $^{-1}$, respectively. This indicates that these grassclover swards which received low $\mathrm{N}$ inputs in terms of fertilization have a higher efficiency in $\mathrm{N}$ transfer and NUE [64]. However, the regression equations did not confirm a strong correlation of $\mathrm{N}$ surplus and $\mathrm{N}$ leaching for arable-ley systems managed with low rates of external $\mathrm{N}$ supplied. The same limited correlation between surplus $\mathrm{N}$ and $\mathrm{N}$-leaching was observed by Eriksen et al. [48]. One important factor is the build-up of soil organic matter during the ley years, which can achieve up to $1.3 \mathrm{t}$ of carbon $\mathrm{ha}^{-1}$ year $^{-1}$ in the upper soil layer $(0-30 \mathrm{~cm})$ after its establishment. During the proceeding years, a decrease in sequestration rates is usually observed for permanent grassland, however, it is still a positive trend with increments of $\sim 0.3 \mathrm{tC} \mathrm{ha}^{-1}$ year $^{-1}$ over a 20 -year period [65]. If a C/N of 12 is considered, it indicates an $\mathrm{N}$ sequestration rate of, on average, $100 \mathrm{~kg} \mathrm{~N} \mathrm{ha}^{-1}$ year $^{-1}$ for leys and $23 \mathrm{~kg} \mathrm{~N} \mathrm{ha}^{-1}$ year $^{-1}$ for permanent grassland, which explains most of the residual $\mathrm{N}$ in the different systems.

The clover contents found in the permanent grasslands was still high (data not shown) and may help to explain the high N-balance in the PG240N system due to the combination of fertilizer and BNF. Moreover, the increased amount of fertilizer could result in higher $\mathrm{N}$ supplied from organic $\mathrm{N}$-sources. Even though the PG240N received fertilizer, no differences were observed between the $\mathrm{N}$ yields from the permanent grasslands. This could be due to the process of apparent $\mathrm{N}$ transfer whereby the $\mathrm{N}$-fixating clovers increased soil-N availability which improves the $\mathrm{N}$ uptake of the grasses in the PG system without an added fertilizer [61].

Catch crops have been shown to reduce N-leaching [35]. However, the highest Nleaching was associated with the cover crop even though it had a low field-N-balance. A possible reason could be grazing, and consequently high $\mathrm{N}$ returns through excreta. Urinary $\mathrm{N}$ may typically contribute $70-90 \%$ to total $\mathrm{N}$ lost through leaching because of a much larger specific rate of $\mathrm{N}$ application, compared to fertilizer [66]. Moreover, the grazing of catch crops late in the year causes trampling patches, which triggers the decay of residual plant biomass. Consequently, the N-uptake through the catch crop cannot be entirely maintained as a potential source of $\mathrm{N}$ for the catch crop in the next spring in ley-arable systems. Thus, to make use of grazed catch crops on this system's basis seems to be questionable as on one hand, it provides herbage for dairy but on the other hand it triggers $\mathrm{N}$ shortages for subsequent cereal production and increases the $\mathrm{N}$ load to groundwater. The permanent grassland under slurry-fertilization resulted in a high field-N-balance. This was as a result of $\mathrm{N}$-inputs through BNF and slurry-fertilization which added to $>300 \mathrm{~kg} \mathrm{~N} \mathrm{ha}^{-1}$ year $^{-1}$. This exceeded the $\mathrm{N}$ demand for pasture plants 
and resulted in an $\mathrm{N}$ surplus of up to $149 \mathrm{~kg} \mathrm{~N} \mathrm{ha}^{-1}$ year $^{-1}$. This means fertilizer planning is necessary while accounting for the BNF.

Our results indicated that across all the treatments, a low level of $\mathrm{N}$ surplus was observed on the field-level. This can be attributed to several factors. In the current farming system (low-input system) a high share of $\mathrm{N}$ is stored as nutrients to be utilized by the sub-sequent catch crop. This is contradictory to the high-input high-output confinement system based on forage maize and high rates of concentrate feeding. It is therefore possible that in our low-input system, the high soil organic matter improves the soil properties and its functions. It was also suggested by Crème et al. [67] that the soil organic matter can counteract GHG emissions and enhance $\mathrm{C}$ sequestration. A study conducted by Nyameasem et al. [34], on the same experimental site, reported low levels of $\mathrm{N}_{2} \mathrm{O}$ emissions which further indicates the effective use of $\mathrm{N}$ in the low-input system [20]. With regard to the $\mathrm{N}$ on a farm-level, a low-input ley-systems based on grazing allows for high productivity in combination with high biodiversity effects [68], low GHG emissions [16,34] and milk production with a low carbon footprint, thereby resulting in eco-efficient dairy systems [69]. These low-input systems could therefore serve as a platform in order to reduce the negative environmental effects associated with dairy farming in northern Germany which will adhere to the European Union Nitrate Directive [8], the Water Framework Directive [9] and the Groundwater Directive [10], organizations that aim to protect both surface and groundwater from agricultural use.

\section{Conclusions}

This study demonstrated that the combination of fertilization and grazing of a cover crop caused the highest level of N-leaching, while the omission of fertilization and herbage$\mathrm{N}$ removed as cuts for silage substantially reduced leaching losses. Grazed leys indicated high herbage production for dairy systems and the highest field-N-balances. However, high field-N-balances of grazed grass-clover-leys were not an appropriate indicator to predict $\mathrm{N}$-leaching losses as high amounts of $\mathrm{N}$ are sequestered in the soil and plant residues. Thus, in ley-arable systems where the intensity of external $\mathrm{N}$ supply is low, a high proportion of $\mathrm{N}$ for the arable unit is derived from the plant residuals of leys. In conclusion, this low-input system can still maintain high productivity while simultaneously reducing the negative environmental effects associated with dairy farming such as N-leaching which can serve as a solution to the EU Nitrate Directive which aims to protect groundwater from nitrate pollution that is caused by agriculture.

Author Contributions: Conceptualization, H.P.J.S., T.R. and F.T.; Methodology, R.L. and T.R.; Software, C.K.; Formal analysis, C.K., R.L. and H.P.J.S.; Investigation, R.L.; Data curation, C.K.; Writingoriginal draft preparation, H.P.J.S.; Writing-review and editing, T.R., C.K. and F.T.; Visualization, T.R., R.L. and F.T.; Supervision, T.R. and F.T.; Funding acquisition, F.T. All authors have read and agreed to the published version of the manuscript.

Funding: H.P.J.S. is supported by the Evangelisches Studienwerk Villigst foundation, under the research program: "Third Ways of Feeding the World", and who provided funding in the form of a doctoral scholarship. This project was part of the Eco-efficiency of pasture based milk production; State Schleswig-Holstein (Title: 1317-894 30-MG30). This project also received funding from SusAn, an ERA-Net co-funded under European Union's Horizon 2020 research and innovation program (https: / /www.era-susan.eu/ (accessed on 20 October 2021)), Grant Agreement no. 696231, and the Federal Ministry of Food and Agriculture, Germany, Grant Agreement no. 2817ERA13D. The authors acknowledge financial support by Land Schleswig-Holstein within the funding program Open Access Publikationsfonds.

Acknowledgments: The authors would like to thank the anonymous reviewers for valuable comments to improve the quality of this article. Terminology in this article follows the recommendations of the International Forage and Grazing Terminology Committee.

Conflicts of Interest: The authors declare no conflict of interest. 


\section{References}

1. Biernat, L.; Taube, F.; Vogeler, I.; Reinsch, T.; Kluß, C.; Loges, R. Is organic agriculture in line with the EU-Nitrate directive? On-farm nitrate leaching from organic and conventional arable crop rotations. Agric. Ecosyst. Environ. 2020, $298,106964$. [CrossRef]

2. Wachendorf, M.; Büchter, M.; Trott, H.; Taube, F. Performance and environmental effects of forage production on sandy soils. II. Impact of defoliation system and nitrogen input on nitrate leaching losses. Grass Forage Sci. 2004, 59, 56-68. [CrossRef]

3. Swanepoel, P.; Du Preez, C.C.; Botha, P.R.; Snyman, H. A critical view on the soil fertility status of minimum-till kikuyu-ryegrass pastures in South Africa. Afr. J. Range Forage Sci. 2015, 32, 113-124. [CrossRef]

4. Greer, K.D.; Pittelkow, C. Linking Nitrogen Losses with Crop Productivity in Maize Agroecosystems. Front. Sustain. Food Syst. 2018, 2, 29. [CrossRef]

5. Torstensson, G.; Aronsson, H.; Bergström, L. Nutrient Use Efficiencies and Leaching of Organic and Conventional Cropping Systems in Sweden. Agron. J. 2006, 98, 603-615. [CrossRef]

6. Harrison, S.; McAree, C.; Mulville, W.; Sullivan, T. The problem of agricultural 'diffuse' pollution: Getting to the point. Sci. Total Environ. 2019, 677, 700-717. [CrossRef] [PubMed]

7. Reinhard, S.; Linderhof, V. Convergence of EU nitrogen surplus, the RDP indicator of water quality. Ecol. Indic. 2015, 59, 19-26. [CrossRef]

8. ECC. Directive 91/676/EC of the European Parliament and of the Council of 12 December 1991 on the protection of waters against pollution caused by nitrates from agricultural sources. Off. J. Eur. Union L 1991, 375, 1-8. Available online: http: / / data.europa.eu/eli/dir/1991/676/oj (accessed on 8 February 2021).

9. ECC. Directive 2000/60/EC of the European Parliament and of the Council establishing a framework for the Community action in the field of water policy. Off. J. Eur. Communities 2000, 327, 1. Available online: http:/ / data.europa.eu/eli/dir/2000/60/oj (accessed on 8 February 2021).

10. ECC. Directive 2006/118/EC of the European Parliament and of the Council of 12 December 2006 on the protection of groundwater against pollution and deterioration. Off. J. Eur. Union L 2006, 372, 19. Available online: http:/ / data.europa.eu/eli/dir/2006/118 /oj (accessed on 8 February 2021).

11. Sutton, M.A.; Howard, C.M.; Brownlie, W.J.; Skiba, U.; Hicks, W.K.; Winiwarter, W.; van Grinsven, H.; Bleeker, A.; Westhoek, H.; Oenema, O.; et al. The European Nitrogen Assessment 6 years after: What was the outcome and what are the future research challenges? In Proceedings of the International Conference on Innovative Solutions for Sustainable Management of Nitrogen, Aarhau, Denmark, 25-28 June 2017; pp. 40-49.

12. Galloway, C.; Conradie, B.; Prozesky, H.; Esler, K. Are private and social goals aligned in pasture-based dairy production? J. Clean. Prod. 2018, 175, 402-408. [CrossRef]

13. Bellarby, J.; Foereid, B.; Hastings, A.F.S.J.; Smith, P. Cool Farming: Climate Impacts of Agriculture and Mitigation Potential; Greenpeace Int: Amsterdam, The Netherlands, 2008; p. 44. Available online: https://eprints.lancs.ac.uk/id/eprint/68831 (accessed on 25 March 2021).

14. Luo, J.; Balvert, S.F.; Wise, B.; Welten, B.; Ledgard, S.F.; de Klein, C.A.M.; Lindsey, S.; Judge, A. Using alternative forage species to reduce emissions of the greenhouse gas nitrous oxide from cattle urine deposited onto soil. Sci. Total Environ. 2018, 610-611, 1271-1280. [CrossRef] [PubMed]

15. Carlton, A.J.; Cameron, K.C.; Di, H.J.; Edwards, G.R.; Clough, T.J. Nitrate leaching losses are lower from ryegrass/white clover forages containing plantain than from ryegrass/white clover forages under different irrigation. N. Z. J. Agric. Res. 2018, 62, 150-172. [CrossRef]

16. Loza, C.; Reinsch, T.; Loges, R.; Taube, F.; Gere, J.I.; Kluß, C.; Hasler, M.; Malisch, C.S. Methane Emission and Milk Production from Jersey Cows Grazing Perennial Ryegrass-White Clover and Multispecies Forage Mixtures. Agriculture 2021, 11, 175. [CrossRef]

17. Loges, R.; Kelm, M.; Taube, F. Nitrogen balances, nitrate leaching and energy efficiency of conventional and organic farming systems on fertile soils in Northern Germany. Adv. GeoEcol. 2006, 38, 407-414.

18. Nadeem, S.; Hansen, S.; Azzaroli Bleken, M.; Dörsch, P. $\mathrm{N}_{2} \mathrm{O}$ emission from organic barley cultivation as affected by green manure management. Biogeosciences 2012, 9, 2747-2759. [CrossRef]

19. Schmeer, M.; Loges, R.; Dittert, K.; Senbayram, M.; Horn, R.; Taube, F. Legume-based forage production systems reduce nitrous oxide emissions. Soil Tillage Res. 2014, 143, 17-25. [CrossRef]

20. Reinsch, T.; Malisch, C.; Loges, R.; Taube, F. Nitrous oxide emissions from grass-clover swards as influenced by sward age and biological nitrogen fixation. Grass Forage Sci. 2020, 75, 372-384. [CrossRef]

21. Lorenz, H.; Reinsch, T.; Kluß, C.; Taube, F.; Loges, R. Does the Admixture of Forage Herbs Affect the Yield Performance, Yield Stability and Forage Quality of a Grass Clover Ley? Sustainability 2020, 12, 5842. [CrossRef]

22. Buckwell, A.; Uhre, A.N.; Williams, A.; Poláková, J.; Blum, W.E.H.; Schiefer, J.; Lair, G.J.; Heissenhuber, A.; Schieß1, P.; Krämer, C.; et al. The Sustainable Intensification of European Agriculture; IEEP: Brussels, Belgium, 2014. Available online: https: //ieep.eu/publications/sustainable-intensification-of-european-agriculture (accessed on 15 March 2021).

23. Schipanski, M.; Barbercheck, M.; Douglas, M.R.; Finney, D.M.; Haider, K.; Kaye, J.P.; Kemanian, A.; Mortensen, D.A.; Ryan, M.R.; Tooker, J.; et al. A framework for evaluating ecosystem services provided by cover crops in agroecosystems. Agric. Syst. 2014, 125, 12-22. [CrossRef] 
24. Salonen, J.; Ketoja, E. Undersown cover crops have limited weed suppression potential when reducing tillage intensity in organically grown cereals. Org. Agric. 2020, 10, 107-121. [CrossRef]

25. Christensen, B.T.; Rasmussen, J.; Eriksen, J.; Hansen, E.M. Soil carbon storage and yields of spring barley following grass leys of different age. Eur. J. Agron. 2009, 31, 29-35. [CrossRef]

26. Selbie, D.R.; Buckthought, L.E.; Shepherd, M.A. The Challenge of the Urine Patch for Managing Nitrogen in Grazed Pasture Systems; Elsevier: Amsterdam, The Netherlands, 2015; Volume 129. Available online: https:/ /www.sciencedirect.com/science/article/ abs/pii/S0065211314000054 (accessed on 20 October 2021).

27. Aarts, H.; Biewing, E.; Van Keulen, H. Dairy farming systems based on efficient nutrient management. Neth. J. Agric. Sci. 1992, 40, 285-299. [CrossRef]

28. Simon, P.L.; de Klein, C.A.; Worth, W.; Rutherford, A.J.; Dieckow, J. The efficacy of Plantago lanceolata for mitigating nitrous oxide emissions from cattle urine patches. Sci. Total Environ. 2019, 691, 430-441. [CrossRef]

29. Kühl, S.; Gassler, B.; Spiller, A. Labeling strategies to overcome the problem of niche markets for sustainable milk products: The example of pasture-raised milk. J. Dairy Sci. 2017, 100, 5082-5096. [CrossRef] [PubMed]

30. Weinrich, R.; Kühl, S.; Zühlsdorf, A.; Spiller, A. Consumer attitudes in Germany towards different dairy housing systems and their implications for the marketing of pasture raised milk. Int. Food Agribus. Manag. Rev. 2014, 17, 205-222. [CrossRef]

31. Peyraud, J.L.; van den Pol-van Dasselaar, A.; Dillon, P.; Delaby, L. Producing milk from grazing to reconcile economic and environmental performances. In Proceedings of the 23th General Meeting of the European Grassland Federation, Kiel, Germany, 29 August-2 September 2010; Volume 15, pp. 865-879. Available online: https://library.wur.nl/WebQuery/wurpubs/402666 (accessed on 22 February 2021).

32. Thomet, P.; Cutullic, E.; Wuest, C.; Elsaesser, M.; Steinberger, S.; Steinwidder, A. Merits of full grazing systems as a sustainable and efficient milk production strategy. Grassl. Sci. Eur. 2012, 16, 273-285. Available online: https://www.cabdirect.org/cabdirect/ abstract/20113347862 (accessed on 19 February 2021).

33. Oenema, O.; Kros, H.; de Vries, W. Approaches and uncertainties in nutrient budgets: Implications for nutrient management and environmental policies. Eur. J. Agron. 2003, 20, 3-16. [CrossRef]

34. Nyameasem, J.; Malisch, C.; Loges, R.; Taube, F.; Kluß, C.; Vogeler, I.; Reinsch, T. Nitrous Oxide Emission from Grazing Is Low across a Gradient of Plant Functional Diversity and Soil Conditions. Atmosphere 2021, 12, 223. [CrossRef]

35. Malcolm, B.J.; Carey, P.L.; I Teixeira, E.; Johnstone, P.R.; Maley, S.C.; De Ruiter, J.M. Potential of catch crops to reduce nitrogen leaching in New Zealand winter grazing systems. J. N. Z. Grasslands 2018, 80, 207-214. [CrossRef]

36. Böldt, M.; Taube, F.; Vogeler, I.; Reinsch, T.; Kluß, C.; Loges, R. Evaluating Different Catch Crop Strategies for Closing the Nitrogen Cycle in Cropping Systems-Field Experiments and Modelling. Sustainability 2021, 13, 394. [CrossRef]

37. Reheul, D.; Cougnon, M.; Kayser, M.; Pannecoucque, J.; Swanckaert, J.; De Cauwer, B.; van den Pol-van Dasselaar, A. Sustainable intensification in the production of grass and forage crops in the Low Countries of north-west Europe. Grass Forage Sci. 2017, 72, 369-381. [CrossRef]

38. Chen, S.; Lin, S.; Loges, R.; Reinsch, T.; Hasler, M.; Taube, F. Independence of seasonal patterns of root functional traits and rooting strategy of a grass-clover sward from sward age and slurry application. Grass Forage Sci. 2016, 71, 607-621. [CrossRef]

39. Reinsch, T.; Loges, R.; Kluß, C.; Taube, F. Renovation and conversion of permanent grass-clover swards to pasture or crops: Effects on annual N 2 O emissions in the year after ploughing. Soil Tillage Res. 2018, 175, 119-129. [CrossRef]

40. Mohrlok, U. Bilanzmodelle in der Grundwasserhydraulik: Quantitative Beschreibung von Strömung und Transport im Untergrund; Karlsruhe University: Karlsruhe, Germany, 2009. Available online: https:/ / www.ksp.kit.edu/9783866443976 (accessed on 9 March 2021).

41. Löpmeier, F.J. Berechnung der Bodenfeuchte und Verdunstung mittels agrarmeteorologischer Modelle. Z. Bewässerungswirtsch 1992, 29, 157-167.

42. Häckel, H. Meteorologie, Ulmer, Stuttgart, 4th ed.; INFINIBU Das Buchuniversum: Düsseldorf, Germany, $1999 ;$ p. 448.

43. Jensen, H.H.; Loges, R.; Jørgensen, F.V.; Vinther, F.P.; Jensen, E.S. An empirical model for quantification of symbiotic nitrogen fixation in grass-clover mixtures. Agric. Syst. 2004, 82, 181-194. [CrossRef]

44. DWD. Temperatur: Langjährige Mittelwerte 1991-2020. Available online: https://www.dwd.de/bvbw/generator/ DWDWWW/Content/Oeffentlichkeit/KU/KU2/KU21/klimadaten/german/nieder_8110_akt_html,templateId=raw, property=publicationFile.html/nieder_8110_akt_html.Dtsch.Wetterd (accessed on 17 January 2021).

45. R Core Team. R: A Language and Environment for Statistical Computing; R Foundation for Statistical Computing: Vienna, Austria, 2020. Available online: https://www.r-project.org/ (accessed on 20 October 2021).

46. Kozak, M.; Piepho, H.-P. What's normal anyway? Residual plots are more telling than significance tests when checking ANOVA assumptions. J. Agron. Crop. Sci. 2017, 204, 86-98. [CrossRef]

47. Kunrath, T.R.; de Berranger, C.; Charrier, X.; Gastal, F.; de Faccio Carvalho, P.C.; Lemaire, G.; Emile, J.-C.; Durand, J.-L. How much do sod-based rotations reduce nitrate leaching in a cereal cropping system? Agric. Water Manag. 2015, 150, 46-56. [CrossRef]

48. Eriksen, J.; Askegaard, M.; Rasmussen, J.; Søegaard, K. Nitrate leaching and residual effect in dairy crop rotations with grassclover leys as influenced by sward age, grazing, cutting and fertilizer regimes. Agric. Ecosyst. Environ. 2015, $212,75-84$. [CrossRef] 
49. Malcolm, B.J.; De Ruiter, J.M.; Dalley, D.E.; Carrick, S.; Waugh, D.; Arnold, N.P.; Dellow, S.J.; Beare, M.H.; Johnstone, P.R.; Wohlers, M.; et al. Catch crops and feeding strategy can reduce the risk of nitrogen leaching in late lactation fodder beet systems. N. Z. J. Agric. Res. 2020, 63, 44-64. [CrossRef]

50. Ledgard, S.; Schils, R.; Eriksen, J.; Luo, J. Environmental impacts of grazed clover/grass pastures. Irish J. Agric. Food Res. 2009, 48, 209-226. Available online: http:/ /hdl.handle.net/11019/649 (accessed on 27 January 2021).

51. Acharya, B.S.; Rasmussen, J.; Eriksen, J. Grassland carbon sequestration and emissions following cultivation in a mixed crop rotation. Agric. Ecosyst. Environ. 2012, 153, 33-39. [CrossRef]

52. Askegaard, M.; Olesen, J.E.; Rasmussen, I.; Kristensen, K. Nitrate leaching from organic arable crop rotations is mostly determined by autumn field management. Agric. Ecosyst. Environ. 2011, 142, 149-160. [CrossRef]

53. Luo, J.; Kelliher, F. Partitioning of Animal Excreta $\mathrm{N}$ into Urine and Dung and Developing the $\mathrm{N}_{2} \mathrm{O}$ Inventory; Ministry for Primary Industries: Wellington, New Zealand, 2010; pp. 1-19. Available online: https://www.mpi.govt.nz/dmsdocument/2962/ (accessed on 11 December 2020).

54. Viljoen, C.; Van Der Colf, J.; Swanepoel, P.A. Benefits Are Limited with High Nitrogen Fertiliser Rates in Kikuyu-Ryegrass Pasture Systems. Land 2020, 9, 173. [CrossRef]

55. Lemaire, G.; Gastal, F. N Uptake and Distribution in Plant Canopies. In Diagnosis of the Nitrogen Status in Crops; Springer: Berlin/Heidelberg, Germany, 1997; pp. 3-43.

56. Capper, J.; Cady, R. A comparison of the environmental impact of Jersey compared with Holstein milk for cheese production. J. Dairy Sci. 2012, 95, 165-176. [CrossRef] [PubMed]

57. Knowlton, K.F.; Wilkerson, V.A.; Casper, D.P.; Mertens, D.R. Manure nutrient excretion by Jersey and Holstein cows. J. Dairy Sci. 2010, 93, 407-412. [CrossRef]

58. Svoboda, N.; Taube, F.; Kluß, C.; Wienforth, B.; Kage, H.; Ohl, S.; Hartung, E.; Herrmann, A. Crop production for biogas and water protection-A trade-off? Agric. Ecosyst. Environ. 2013, 177, 36-47. [CrossRef]

59. Carey, P.L.; Cameron, K.; Di, H.J.; Edwards, G. Comparison of nitrate leaching from oats and Italian ryegrass catch crops following simulated winter forage grazing: A field lysimeter study. N. Z. J. Agric. Res. 2017, 60, 298-318. [CrossRef]

60. Rotz, C.A.; Taube, F.; Russelle, M.P.; Oenema, J.; Sanderson, M.A.; Wachendorf, M. Whole-Farm Perspectives of Nutrient Flows in Grassland Agriculture. Crop. Sci. 2005, 45, 2139-2159. [CrossRef]

61. Enriquez-Hidalgo, D.; Gilliland, T.J.; Hennessy, D. Herbage and nitrogen yields, fixation and transfer by white clover to companion grasses in grazed swards under different rates of nitrogen fertilization. Grass Forage Sci. 2015, 71, 559-574. [CrossRef]

62. Martin, K.; Edwards, G.; Bryant, R.; Hodge, M.; Moir, J.; Chapman, D.; Cameron, K. Herbage dry-matter yield and nitrogen concentration of grass, legume and herb species grown at different nitrogen-fertiliser rates under irrigation. Anim. Prod. Sci. 2017, 57, 1283-1288. [CrossRef]

63. Phelan, P.; Casey, I.A.; Humphreys, J. The effects of simulated summer-to-winter grazing management on herbage production in a grass-clover sward. Grass Forage Sci. 2014, 69, 251-265. [CrossRef]

64. Nyfeler, D.; Huguenin-Elie, O.; Suter, M.; Frossard, E.; Lüscher, A. Grass-legume mixtures can yield more nitrogen than legume pure stands due to mutual stimulation of nitrogen uptake from symbiotic and non-symbiotic sources. Agric. Ecosyst. Environ. 2011, 140, 155-163. [CrossRef]

65. Loges, R.; Bunne, I.; Reinsch, T.; Malisch, C.; Kluß, C.; Herrmann, A.; Taube, F. Forage production in rotational systems generates similar yields compared to maize monocultures but improves soil carbon stocks. Eur. J. Agron. 2018, 97, 11-19. [CrossRef]

66. Monaghan, R.M.; Hedley, M.J.; Di, H.J.; McDowell, R.; Cameron, K.; Ledgard, S. Nutrient management in New Zealand pastures-Recent developments and future issues. N. Z. J. Agric. Res. 2007, 50, 181-201. [CrossRef]

67. Crème, A.; Rumpel, C.; Le Roux, X.; Romian, A.; Lan, T.; Chabbi, A. Ley grassland under temperate climate had a legacy effect on soil organic matter quantity, biogeochemical signature and microbial activities. Soil Biol. Biochem. 2018, 122, 203-210. [CrossRef]

68. Lorenz, H.; Reinsch, T.; Hess, S.; Taube, F. Is low-input dairy farming more climate friendly? A meta-analysis of the carbon footprints of different production systems. J. Clean Prod. 2018, 211, 161-170. [CrossRef]

69. Reinsch, T.; Loza, C.; Malisch, C.S.; Vogeler, I.; Kluß, C.; Loges, R.; Taube, F. Toward Specialized or Integrated Systems in Northwest Europe: On-Farm Eco-Efficiency of Dairy Farming in Germany. Front. Sustain. Food Syst. 2021, 5, 167. [CrossRef] 